\title{
Berlin universities jockey for position after reunification
}

Munich. German reunification has created fierce competition for money, students and courses between three large universities in Berlin. The outcome of that rivalry will shape the health of science in Germany's once and future capital city.

The Free University and the Technical University in the west part of Berlin share the same pot of funding with east Berlin's Humboldt University, although a generation of isolation spawned different teaching and research structures and the duplication of many courses.

After reunification, the German science council, the Wissenschaftsrat, evaluated Humboldt with the idea of bringing eastern institutions into line with their western counterparts. But long after most east German universities completed the process, the Humboldt continues to fight against many decisions that it feels are unfair. At the same time, the two western universities see the 'renewal' of the Humboldt as a drain on their own resources.

The Humboldt, Berlin's oldest university, was established in 1810 by Wilhelm von Humboldt, whose theory of the unity of teaching and research remains in the German constitution, and soon became one of Europe's leading universities. Then called the Friedrich Wilhelm University, it was suppressed by the Nazis and finally closed in 1944 after 70 per cent of its buildings were destroyed. In 1945 it was reopened in the Russian sector of occupied Berlin and in 1949 it was given its present name. Today it has nearly 20,000 students.

The King's Technical College was founded on the site of the 'Bergakademie' (established in 1770) and achieved university status around the turn of the century. In the 1930s it became strongly associated with national socialism, and all Jewish academics and Nazi dissidents were expelled. After the war it was reopened as the Technical University to dissociate itself from its past. Its current enrolment is 37,000 .

Politics also led to the creation of West Berlin's second university. In 1948, at the beginning of the Cold War, the Humboldt expelled western students, who agitated for their own university. The result, financed by the military government in the US sector of Berlin, was the Free University, which now has 61,000 students.

The communist government separated research from higher education and placed it in institutes belonging to the national Academy of Sciences. The 1990 Higher Education Renewal Programme required research to be reintegrated into eastern university systems (see Nature 362, 775; 1993), leading to the construction of new facilities on top of the extensive renovation required to raise the infrastructure to western levels.

The cost of this restructuring has taken its toll on Berlin's budget for higher education. The Free University has lost 55 faculty posts and an additional 110 posts have been temporarily frozen. The Technical University has lost 40 posts and 80 have been frozen. The already high ratio of students to staff at these universities (66:1 and 70:1 respectively) is likely to increase because, by law, enrolment in some subjects can be reduced only when posts are eliminated, not simply frozen. The western universities also attract students from the eastern sector who prefer to study in the better facilities that the west offers.

The need to coordinate courses is another problem. In early 1991, attempts were made to close down departments at the Humboldt on the grounds that it was being restructured anyway. But such back-door decisions by the Berlin senate, the legislative body for the local government, were successfully challenged in the courts.

In some departments, such as law, history and philosophy, the process of closure was already under way and posts have been reassigned. As a result of the court ruling, universities in some cases are paying for two people to occupy the same faculty post.

Academic departments may be closed only after an evaluation by the Wissenschaftsrat of equivalent departments in all three universities. But the Humboldt still feels at a disadvantage because a history of inadequate financing has made it difficult to compete with western departments.

In several cases, duplication has been eliminated by combining departments and housing them at one site. But the unequal wages and different scientific qualifications have caused social problems and generated complaints from those at the Humboldt. For example, the Free University was chosen as the site for a combined veterinary medicine department despite the fact that the Humboldt's department was rated higher. The Berlin senate decided that its rural location was more appropriate for handling large animals and that its facilities were better. And last summer the Berlin senate combined two electronic engineering departments on the understanding that the Humboldt could continue to send students through the new department. But its department has effectively been closed after the senate failed to keep its promise.

Other unions have been less acrimonious. For example, in October agricultural sciences were transferred from the Technical University to the Humboldt, with food technology moving in the other direction.

\section{IMAGE UNAVAILABLE FOR COPYRIGHT REASONS}

\section{Differing pasts merge into a common future for, from top, the Free, Technical and Humboldt universities.}

But attempts to rationalize Berlin's three costly university clinics, the Humboldt's Charité with 2,450 beds and the Free University's two clinics, the Rudolf Virchow with 1,700 beds and the Steglitz, with 1,350 beds, were attacked so strongly by each university that in March the senate decided to make the two larger clinics the same size as the smallest one. Along with that reduction, the number of students will decline from more than 1,000 to 600 and the number of lecturers from 400 to 330 , with the senate dictating the areas of specialization.

Although a limited level of scientific interchanges between east and west existed despite the Wall, the new opportunities to broaden that cooperation are not being fully exploited. Instead, university researchers prefer to form links with research institutes because the competition for jobs and funding has proved to be a disincentive for cooperation.
Comelia Koob 